\title{
Empirical Analysis of Non-Performing Loans and Liquidity of Deposit Money Banks: Nigeria Experience
}

\author{
Ibitomi Taiwo $^{1 *}$ \\ Micah Elton Ezekiel Mike ${ }^{2}$ \\ University of Ilorin, Kwara State, Nigeria ${ }^{1}$ \\ Air Force Institutes of Technology, Kaduna ${ }^{2}$
}

\begin{abstract}
Nigerian Deposit Money Banks (DMBs) tend to have suffered the plight of NonPerforming Loans (NPLs) in recent times in no small quantum. Consequently, a large chunk of them have had to increase their loan loss provisions and this may dwindle their liquidity. This study investigates the effect of non-performing loans on liquidity of Deposit Money Banks (DMBs) in Nigeria. A panel regression analysis was performed on a data of 15 quoted DMBs from 2009 to 2019, in order to examine the correlation between the explained variable (banks' liquidity) and Non-Performing Loans (NPL) while other explanatory variables- Capital Adequacy Ratio (CAR), Bank Size (BS), Loan Growth (LG), Monetary Policy Rate (MPR), Gross Domestic Product (GDP) and Inflation were taken into consideration. Data were extracted from the banks' yearly financial statements and the World Bank Financial Statistics. Based on the empirical findings, the study found only four variables-Non Performing Loans, Capital Adequacy Ratio, Bank Size and Inflation significantly related at $5 \%$ significant level with banks' liquidity while the other three; Gross Domestic Product, Loan Growth and Monetary Policy Rate were identified as insignificant. The finding also revealed that NPLs has negative effect on banks' liquidity while CAR, BS and INF showed positive relationship. The study recommends strict compliance of banks with the NPLs tolerable limit set by the Central bank. It also suggests that the CBN take proactive measure to ensure the banks' compliance with the minimum capital requirement.
\end{abstract}

Keywords: Banks, Financial Institutions, Liquidity, Non-Performing Loans, Performance

*Corresponding author: Ibitomi Taiwo; Email: prof4real4all@gmail.com DOI: https://doi.org/10.37227/JIBM-2021-09-1167

\section{Introduction}

Financial intermediation is a vital functions of any financial institutions. They make funds available to individuals and corporate bodies to grow businesses and investment via enhanced industrialization. Liquidity is therefore a prominent tool for achieving that essential role. Banks' liquidity entails their ability to finance transactions efficiently in order to meet withdrawal demands, investments and loan portfolio. The performance of individual banks and the entire banking system is largely influenced by banks' behaviour to assets and liquidity management. The significance of liquidity management to banks calls for the Central Bank of Nigeria (CBN) intervention in initiating minimum liquidity threshold, so as 
to enhance customers' confidence in the banking industry and ultimately the banks' operational performance. It implies therefore that the importance of liquidity in the discharge of banks' role cannot be over emphasized. However, there are some challenges banks encounter with regards to liquidity such as liquidity risk, nonperforming loans and lots more. For the purpose of this study, the plight of Non-performing loans is observed. Anecdotal evidence suggests that some banks grant powerful Nigerians loans, who may have paid part of such loans as gratification to some bank staff in order to circumvent the loan procedure.

This ugly trend seems to result to huge unpaid loans in the banking industry. According to the statement enunciated by two (2) members of the Central Bank of Nigeria's Monetary Policy Committee via the bank's website, four (4) deposit money banks whose identity were made unknown, have been observed operating with too many Non- Performing Loans (NPLs ) on their books and with liquidity ratio below the minimum requirement of $30 \%$ (Samuel, 2017). CBN (2016) revealed that a liquidity shortfall of N2.3trillion as at 2016 end-December as against N1.93trillion for 2015 within the banking industry. The liquidity ratio of the industry consequently declined to $6.76 \%$ in December 2016 from $10.24 \%$ as recorded for that of 2015 . The report also disclosed the decrease in market liquidity from N175.15billion as at June 2016 to N159.29billion as at that year end (CBN, 2016).

The report revealed from another angle that about $47 \%$ of the Nigerian Banking Industry's Impaired loans were collectively held by its top five banks - Zenith bank plc, Guaranty Trust bank, First bank Nigeria plc, United bank for Africa and Access bank therefore maintaining Non-performing loan ratio above the regulatory limit of $5 \%$. The report also disclosed that the industry's NPL had increased from N1.678trillion as at Juneend 2016 to N2.084trillion recorded for that year end. The trend of NPL ratio over the years particularly after the 2004-2005 recapitalization exercise showed that 6 out of the 11-year period to be considered in this study, generated NPLs ratio greater than the minimum requirement in the following years, 2007(9.5\%), 2008(7.2\%), 2009(37.3\%), 2010(20.1\%), 2011(6\%) and 2016(12.8\%)(World Bank Group (WBG), 2016).

The drop in the Nigerian banking Industry's liquidity especially between 2015 and 2016 has been attributed to a number of factors: increase in monetary policy rate from $12 \%$ to $14 \%$, economic recession, volatility of exchange rate etc. However, huge unpaid loans cannot be disregarded as a contributing factor in this context as some deposit money banks have had to increase their loan loss provision after their unpalatable experience in relation to non-performing loans and its resultant effect on their liquidity position. For instance, Zenith bank's loan loss provision increased by $198 \%$ to N42.9billion in first quarter of 2017 from N14.23billion in first quarter of 2016; Stanbic IBTC's loan loss provision increased by N65.1\% from N8.45billion in first quarter of 2016 to N13.95\% in first quarter of 2017; Ecobank's loan loss provision increased by $62.4 \%$ from N25.99billion to N42billion; Wema bank's provision against loan loss increased by $43.7 \%$ from N61million to N88million etc. (Bonny \& Motolani, 2017). This study therefore centres on examining the effect nonperforming loans have had on Deposit Money Banks' liquidity in Nigeria.

This study is considered important as the place of liquidity cannot be sidelined since banks' lending is largely financed therewith. Moreso, the attention of potential investors is concentrated to banks which realise excess liquidity and consequently record liquidity ratio beyond the regulatory requirement. In addition, bank run is driven away and customers' confidence in the industry tends to grow stronger when required funds are put in place hence the importance of bank liquidity cannot be underrated. A large number of studies have been conducted in relation to nonperforming loans and bank performance in Nigeria (Samuel, 
2011; Edirin, 2014; Daniel, 2016; Ojo \& Somoye, 2016; Lawrence, 2017). Also other studies have examined how nonperforming loans influence the financial performance of banks in specified countries (Lucy \& Julius, 2016; Mohammed \& Gang, 2016). However, little attention tends to have been paid by local authors on how Nigerian banks' liquidity has been influenced by non-performing loans particularly after the 2005 recapitalization exercise in the industry, as incidence regarding failed banks had sprung up afterwards warranting the intervention of the $\mathrm{CBN}$ and Nigerian Deposit Insurance Corporation (NDIC) towards protecting depositors' interest and banks' restructuring. The scope of this study covered a period of 11 years from the period of 2009 to a period of 2019.

\section{Conceptual Framework}

\section{Literature Review}

\section{Liquidity}

There are mainly two forms of liquidity to be considered in this study: Funding and Market liquidity.

\section{Funding Liquidity}

It is described as the ease and speed with which funds are raised by financial institutions in order to meet their essential financial obligations (say, cash withdrawal commitments, asset acquisition, investment portfolio) when they fall due. Funds are obtained by these institutions through the following sources: demand deposit, interbank market, sale of intangible assets, sale of property equipment, capital market etc.

Market Liquidity

It entails the ability of firms to influence their asset securities in relation to prices. It is also described as banks' ability to trade their assets or securities at low cost within short notice and at reasonable and fair prices. In other words, when banks are able to trade their assets anytime within the market hours with little loss of value and at competitive prices, the market is considered liquid (Owino, Wagude \& Mulwa, 2021). However, when it seems difficult for them to take this move, then they tend to suffer market liquidity risk.

\section{Non-performing Loans}

According to Basel Committee on Banking Supervision (2001), Non-performing loan is considered when a bank affirms that a customer ( debtor) cannot fulfill his/her obligation in relation to payment of interest and/or principal as at when due. Non-performing loans also involve loans whose credit qualities have worsened and the full recovery of principal and/or interest payment at maturity date is in question (CBN, 2015). Clementina and Hamilton (2014) viewed non-performing loans as catalyst for reducing banks' liquidity hence it influences the growth of the real sector and the entire economy at large. The author asserted further that non-performing loans occur when amortization schedules are not realizable as at when due owing to overcharged loan interest. Bamoriya and Jain (2013) identified the main determinants of NPLs in the Nigerian banking industry as default on loan repayment, fraudulent practices, advances without adequate collateral or references and division of funds. CBN (2010) asserted that non-performing loan facilities can be grouped into three divisions: substandard loan, doubtful loan and loan loss. Substandard loan facilities are considered outstanding principal and/or interest for more than 90 days but less than 180 days; doubtful facilities are unpaid principal amount and/or interest considered due for at least 180 days but less than 360 days; loan loss are considered loan amount due for payment but which 
remains uncollected for 360 days or more. The CBN in a bid to cushion the menace of NPLs in the banking industry, has required banks to maintain a specified loan loss provision i.e. $10 \%, 50 \%$ and $100 \%$ respectively against these 3 NPLs divisions so as to help absorb the shock of unbearable unpaid loans as they arise. NPL is measured as the ratio of total nonperforming loan incurred to total gross loan recorded for a given financial period.

\section{Theoretical Framework}

Holding sufficient resources to meet withdrawal demands of customers is one of the vital obligations of banks however NPLs appear to conflict with this motive particularly when their surge shoot regulatory limit therefore one of the liquidity management theories vis-avis NPL-Moral hazard Hypothesis, is reviewed in this study.

\section{Asymmetric Information and Moral hazard Hypothesis}

In Diamond and Dybvig model (1983), the existence of financial intermediaries is premised on two strands: their liquidity provision and their ability to transform the risk characteristics of assets. Financial Intermediation involves the channeling of funds from the surplus units (savers with excess funds) to the deficit units (user of funds for immediate consumption). Banks are able to transform illiquid long term assets into liquid liabilities through diversification and also requesting investors to postpone their spending/consumption so as to enjoy higher payoff thereafter. However, this transformation process comes with its defects: information Asymmetry, risks etc. Information Asymmetry arises when borrowers possess more information about their projects than lenders do. Information Asymmetry can either be 'ex ante' or 'ex post'. An ex ante Information Asymmetry occurs when lenders have difficulty differentiating between borrowers with different credit risks before being granted the potential loans. This act could result to adverse selection problem. In other words, banks are likely to be liable to risk of unpaid loans when skillful loan analysers meant to identify customers with their different risk capacity, are not in place. An ex post Information Asymmetry arises when only borrowers but not lenders possess adequate knowledge of the expected returns from a project which is made unknown even after the execution of the loan agreement . This act tends to pose moral hazard problem. Moral hazard Hypothesis was first proposed by Keeton and Morris (1987).

Moral hazard problems ensue when borrowers engage deliberately in activities that tend to reduce the likelihood of their loan repayment while adverse selection problems involve activities lenders engage in, which tend to enhance the complement of loan with bad credit risk. The hypothesis suggests that banks suffer liquidity problems when: banks officials intentionally grant loans to customers on the acceptance of questionable assets given the assumption of prompt loan repayment, short payback period, long standing relations with borrowers or considering the financial worth of the customer etc. In addition, some influential customers connive with bank officials to circumvent lending policies when they seek loans, with the mindset that such banks would be restored from failing at all cost in the long run perhaps by the regulators. Therefore these two scenarios may facilitate banks' vulnerability to bad loans and liquidity shortage much importantly since the volume of withdrawals cannot be determined with exactness per time. Jaffee and Russell (1976) identified imperfect information as the main assumption of the hypothesis and suggested credit rationing as a way out. In line with this hypothesis, the study postulates that increase in non-performing loans of banks will lead to decline in their liquidity. 


\section{Empirical Review}

Quite a number of studies have been observed in relation to this subject matter- effect of non-performing loans on liquidity of deposit money banks in Nigeria. Previous studies identified positive link between banks' liquidity and NPLs, from their findings (Berhanu, 2015; Chikoko, 2013; Edirin, 2014; Vodova, 2011). Result from these studies revealed that given banks' efficient and prudent loan policy management, the expected credit risk is, in the long run, offset by the banks' adequate loan loss provision, well-structured liquidity risk management and substantial capital adequacy. Choon, Hooi, Murthi, Yi and Shven (2013) posit that excessive lending influences banks' liquidity capacity and as such increases their liquidity risk.

Previous studies identified negative relationship between banks' liquidity and NPLs (Bloem \& Gorter, 2001; Toby, 2008; Iqbal, 2012; Ionica, 2012; Jane, 2014; Tafirei, 2014; Nigist \& Laximikanthan, 2015). They argued that there tends to be inverse correlation between the banking industry's assets quality measured by NPL and the banks' minimum liquidity ratio. In other words, as the industry's NPLs increases, banks are bound to suffer liquidity challenges and as such their capabilities in meeting the minimum liquidity threshold become weakened. They advocated that the negative impact of NPLs on banks facilitates their illiquidity conditions, influences the threats of insolvency, erodes their capital, results in bank run and eventually leaves them at the mercy of the regulators for possible way out.

Muhammed and Gang (2016) observed an insignificant relationship between these two prominent concepts- banks' liquidity and NPLs. They argued that liquidity creation by Chinese banks stands to be independent and unrelated with NPL changes. They identified liquidity creation as a better measure of risk compared with loan growth employed by prior studies it helps to provide an absolute amount of risk transformation.

Existing literature showed that other factors such as capital, size and loan growth also influence banks' liquidity (Nzioka \& Kariuki, 2021). The relationship between the banks' liquidity and capital has been observed by quite a number of studies which have found positive correlation between these two concepts. The authors argued that as their capital increases, they tend to expand businesses, settle more financial obligations, meet customers' demands, invest in profitable assets and ultimately strive for continuity. They added that the banks' minimum capital requirements are made them strong and resilient; reduced the risk of insolvency and restored the public confidence in their service delivery (Aymen, 2015; Bunda \& Desqui, 2005; Choon et al., 2013, Faroq \& Nasir, 2017; Jane, 2014; Tseganesh, 2012; Vodova, 2011; Gakpo, Anafure \& Mensah, 2021).

Previous studies identified negative relationship between banks' liquidity and their size (Choon et al., 2013; Faroq \& Nasir, 2017; Rauch, Steffen, Hackethal \& Tyrell, 2009; Tannotta, Nocera \& Sironi, 2007). They observed that large banks tend to hold less liquidity compared with the smaller ones. They claimed that large banks maintain huge investment portfolios which stand as a bail out of financial constraints when the need arises. In addition, these large banks have the CBN as the last resort when in short of funds. This reaction however may pose a moral hazard problem as banks' regulators strive to protect their interest at all cost. Unlike the large banks, small banks tend to strive in meeting the minimum liquidity limit therefore they seek to create more liquidity as the need arises.

Vodova $(2011,2013)$ argued that increased lending rate dwindles demands for loanable funds by both deposit money banks and their customers. They claimed this reaction could result into credit crunch and also instigate imbalances between banks' liquidity and Monetary Policy Rate (MPR). Johannes, Sheefeni and Jacob (2016) found that Monetary Policy Rate (MPR) positively but insignificantly related to banks' liquidity. 
Other variables considered in this study were reviewed; while, Anamika and Anil (2016), Bhati and Dezoysa (2012) and Moussa (2015) identified positive relationship between inflation and bank liquidity, as they argued that increase in inflation prompts banks to hold much liquidity than they would otherwise have so as to cushion the resultant effect therefrom on their businesses, Tseganesh (2012), Vodova (2011) realized a negative result. They rather observed that increased inflation tends to conflict with banks' ability to create more liquidity hence their ability to meet demanding obligations suffer. Moreso, Anamika and Anil (2016), Bunda and Desquilbel (2008), Choon et al. (2013), Faroq and Nasir (2017) and Moussa (2015), in their findings realized a positive impact between GDP and bank liquidity as they posit that a buoyant economy spells well on every sector of the nation-the banking industry inclusive, while Dinger (2009), Vodova (2011) found a negative result. Vodova (2013) found Monetary Policy Rate having negative and significant impact on banks' liquidity. The author observed that increased monetary policy rate forces banks to seek alternative sources of accessing funds at interbank market.

\section{Research Gap}

Different studies (Aymen, 2015; Anamika \& Anil, 2016; Chikoko, 2013; Faroq \& Nasir, 2017; Ionica, 2012; Nigist \& Laximikantham, 2015; Tafirei, 2014; Vodova, 2011; Vodova, 2013) have been conducted in relation to liquidity and its determinants across different countries of the world. These studies categorized the determinants into two broad areas: macroeconomic and bank specific factors; NPLs was identified as one of the bank specific factors influencing banks' liquidity (Nzioka \& Kariuki, 2021; Akhigbe \& Akhigbe, 2021). A number of Nigerian studies, Edirin (2014); Ezeamama, Onwuliri and Okoye (2016); Godwin and Comfort (2015); Lawrence and Foluso (2017); Ojo and Somoye (2016) and lots more have concentrated their studies on the degree to which banks' performance (specifically banks' profitability) have been influenced by the menace of huge unpaid loans however considering the liquidity constraints Nigerian banks suffer consequent to NPLs tide, few Nigerian studies was found in this area. It therefore becomes imperative to observe the other measure of banks' performance i.e. banks' liquidity and how it has been affected by banks' trouble loans over the years employed in the study.

\section{Methodology}

The population of the study comprises all deposit money banks operational in Nigeria. A sample of 15 quoted and listed banks were observed; secondary and panel data were extracted from the banks' annual financial reports in relation to the study. Information in respect of banks' liquidity, Capital Adequacy Ratio, Bank size and Loan growth were obtained from their annual audited financial statements while data on GDP, Monetary Policy Rate and Inflation were extracted from the World Bank website. The timeframe selection is subject to examining the plight of nonperforming loans and its effect on bank liquidity particularly after the 2005 recapitalisation exercise. As at when relevant data required for use in this study were collated, 2017 banks' financial reports remained unavailable.

The study adopts the ex post facto research design as it is vital in testing hypotheses about cause-and-effect relationships between variables (Neil, 2010). The panel regression technique was adopted for the study. Pooled OLS, fixed effect and random effect model were observed as well as BP-LM and Hausman test carried out in the study. While BP-LM test was carried out to identify the more appropriate between pooled OLS and fixed/random effect models, Hausman test was conducted to determine the fixed and random effect preferred option. The model of Jane (2014) was adapted for this study 


$$
\begin{gathered}
\mathrm{Y}=\propto+\beta_{1} X_{1}+\beta_{2} X_{2}+\beta_{3} X_{3}+\beta_{4} X_{4}+\epsilon \\
\text { LIQ }=\propto+\beta 1 \mathrm{NPL}+\beta 2 \mathrm{CAR}+\beta 3 \mathrm{BS}+\beta 4 \mathrm{LG}+\epsilon \\
\text { Where LIQ= liquidity ratio } \\
\propto=\text { constant term } \\
X_{1} X_{2} X_{3} X_{4}=\text { regression coefficient variables } \\
X_{1}=\mathrm{NPL}=\text { Non-Performing Loans } \\
X_{2}=\mathrm{CAR}=\text { Capital Adequacy } \\
X_{3}=\mathrm{BS}=\text { Bank Size } \\
X_{4}=\mathrm{LG}=\text { Loan Growth }
\end{gathered}
$$

The model was however modified to capture new variables with which the study's objective (the effect of nonperforming loans on liquidity of DMBs in Nigeria) can better be attained. The adapted model was restructured to include macroeconomic factors such as Gross Domestic Product (GDP), Inflation and Monetary Policy Rate. The reason for the inclusion of these variables is premised on the fact that authors such as: Anamika and Anil (2016); Berhanu (2015); Faroq and Nasir (2017); Mohammed (2015); Gantiah (2012); Ionica(2012); Muhammed and Gang(2016); Uremadu (2009); Vodova (2011); Vodova (2013) etc. have identified them as prominent determinants of banks' liquidity therefore omission of such variables in this study could disrupt achieving a reliable result. Banks' liquidity is employed as the dependent variable while Nonperforming loans as the main independent variable. Bank specific and macroeconomic indicators of liquidity such as Capital Adequacy Ratio (CAR), Bank size, Loan Growth, GDP, Inflation and Monetary Policy Rate (MPR) are considered as the other explanatory variables in the study. The model for the study is therefore expressed thus:

$$
\begin{gathered}
\mathrm{Y}=\mathrm{f}(\mathrm{NPL}, \mathrm{CAR}, \mathrm{BS}, \mathrm{LG}, \mathrm{GDP}, \mathrm{MPR}, \mathrm{INF}) \\
\mathrm{Y}=\propto+\beta_{1} X_{1}+\beta_{2} X_{2}+\beta_{3} X_{3}+\beta_{4} X_{4}+\beta_{5} X_{5}+\beta_{6} X_{6}+\beta_{7} X_{7}+\epsilon \\
\mathrm{LIQ}=\propto+\beta_{1} \mathrm{NPL}+\beta_{2} \mathrm{CAR}+\beta_{3} \mathrm{BS}+\beta_{4} \mathrm{LG}+\beta_{5} \mathrm{GDP}+\beta_{6} \mathrm{MPR}+\beta_{7} \mathrm{INF}+\epsilon
\end{gathered}
$$

The $A$-priori expectation for the study implies that GDP, CAR and INF are positively related to DMBs' liquidity while negative outcome is envisaged on the other variables (NPLs, Loan Growth, Bank size and MPR). 
Table 1. Description of Variables Employed in The Study

\begin{tabular}{|c|c|c|c|c|}
\hline Variables & Measurement & Notation & Data source & Related literature \\
\hline Liquidity ratio & $\begin{array}{l}\text { Liquid asset over } \\
\text { total asset }\end{array}$ & LIQ & $\begin{array}{l}\text { Banks' annual } \\
\text { financial reports }\end{array}$ & $\begin{array}{ll}\text { Vodova(2011), } & \text { Chikoko(2013), } \\
\text { Edirin(2014) } & \\
\end{array}$ \\
\hline $\begin{array}{l}\text { Nonperforming } \\
\text { loans }\end{array}$ & $\begin{array}{l}\text { Nonperforming } \\
\text { loans over total } \\
\text { loans }\end{array}$ & NPL & $\begin{array}{l}\text { Banks' annual } \\
\text { financial reports }\end{array}$ & $\begin{array}{l}\text { Faroq and Nasir(2017), Belete(2015), } \\
\text { Ionica(2012), Toby(2008), }\end{array}$ \\
\hline Loan Growth & $\begin{array}{l}\text { Difference in } \\
\text { current year's } \\
\text { gross loan \& } \\
\text { preceding year's }\end{array}$ & LG & $\begin{array}{l}\text { Banks' annual } \\
\text { financial reports }\end{array}$ & Jane(2014), Tafirei(2014) \\
\hline Bank Size & $\begin{array}{l}\text { Natural log of total } \\
\text { assets }\end{array}$ & $\mathrm{BS}$ & $\begin{array}{l}\text { Banks' annual } \\
\text { financial reports }\end{array}$ & $\begin{array}{l}\text { Rauch, steffen, Hackethal and } \\
\text { Tyrell(2009), Tannotta, Nocera and } \\
\text { Sironi(2007) }\end{array}$ \\
\hline $\begin{array}{l}\text { Capital } \\
\text { Adequacy Ratio }\end{array}$ & 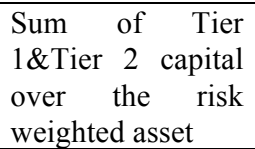 & CAR & $\begin{array}{l}\text { Banks' annual } \\
\text { financial reports }\end{array}$ & $\begin{array}{l}\text { Aymen(2015), Bunda and } \\
\text { desqui(2005), Choon et al.(2013), } \\
\text { Jane(2014) }\end{array}$ \\
\hline Inflation & $\begin{array}{ll}\text { Consumer } & \text { Price } \\
\text { Index }(\mathrm{CPI}) & \end{array}$ & INF & $\begin{array}{l}\text { World Bank } \\
\text { Economic } \\
\text { Outlook } \\
\text { Database }\end{array}$ & $\begin{array}{l}\text { Anamika and Anil(2016), } \\
\text { Moussa(2015), Tseganesh(2012), } \\
\text { Bhati and Dezoysa(2012) }\end{array}$ \\
\hline $\begin{array}{l}\text { Monetary Policy } \\
\text { Rate }\end{array}$ & $\begin{array}{l}\text { Annual monetary } \\
\text { policy rate }\end{array}$ & MPR & $\begin{array}{l}\text { World Bank } \\
\text { Economic } \\
\text { Outlook } \\
\text { Database }\end{array}$ & Johannes, Sheefeni and Jacob(2016) \\
\hline $\begin{array}{l}\text { Gross Domestic } \\
\text { Product }\end{array}$ & $\begin{array}{l}\text { Annual GDP } \\
\text { Growth rate }\end{array}$ & GDP & $\begin{array}{l}\text { World Bank } \\
\text { Economic } \\
\text { Outlook } \\
\text { Database }\end{array}$ & $\begin{array}{ll}\text { Vodova(2011), } & \text { Vodava(2013), } \\
\text { Choonetal.(2013), } & \\
\text { Berhanu(2015) } & \end{array}$ \\
\hline
\end{tabular}

\section{Results and Discussions}

\section{Descriptive Statistics}

The descriptive statistics of all the variables of the model are reported in table 4.1 which shows the number of observations, mean, standard deviation, minimum and maximum values of the explained variable (liquidity) and each of the explanatory variables (NonPerforming Loans, Capital Adequacy Ratio, Bank size, Loan growth, Gross Domestic Product, Inflation and Monetary Policy Rate) used in this study. The measure of dispersion of the model variables are measured by the values of standard deviation as shown in Table 2.

Table 2: Summary of Descriptive Statistics

\begin{tabular}{cccccc} 
Variables & Obs. & Mean & S.D. & Min & Max \\
\hline Liquidity(\%) & 165 & 38.15 & 13.17 & 14.3 & 79 \\
NPL(\%) & 165 & 11.89 & 11.54 & 1.1 & 60.7 \\
CAR(\%) & 165 & 21.06 & 5.89 & 4.3 & 43 \\
BS(Log) & 165 & 18.63 & 2.18 & 13.42 & 21.51 \\
LG(\%) & 165 & 29.89 & 26.36 & -39 & 192 \\
GDP(\%) & 165 & 6.09 & 1.81 & 2.65 & 9.93 \\
MPR(\%) & 165 & 10.36 & 2.54 & 6 & 14 \\
Inf(\%) & 165 & 10.48 & 2.78 & 5.4 & 15.7 \\
\hline
\end{tabular}

Source: Author's Computation, 2020. 


\section{Testing for Multicollinearity}

Multicollinearity among the independent variables was tested using Variance Inflation Factor (VIF). This is necessary because OLS regression technique assumes the absence of perfect linear relationship among the independent variables to expect a high level of accuracy from the estimator.

Table 3: Variance Inflation Factor

\begin{tabular}{ccc} 
Variable & VIF & I/VIF \\
\hline NPL & 2.16 & 0.83 \\
CAR & 3.54 & 0.74 \\
BS & 3.58 & 0.72 \\
LG & 2.78 & 0.79 \\
GDP & 6.03 & 0.59 \\
MPR & 6.66 & 0.57 \\
INF & 4.59 & 0.69 \\
Mean VIF & 4.19 & \\
\hline \multicolumn{3}{l}{ Source: Author's Computation, 2020. }
\end{tabular}

Table 3 shows the VIF and its inverse (also called tolerance level) for all the independent variables. By rule of thumb, any variable whose VIF is greater than 10 is highly collinear and vice-versa. From Table 3, all the variables have VIF that are less than 10 which implies they are not collinear. Gujarati (2009) opines that the closer the value of I/VIF to zero, the greater the degree of multicollinearity while the closer the value of I/VIF to one, the more tendency they don't suffer multicollinearity problem. Therefore, from the Table 3 , all the variables are above 50\% meaning that they are closer to one than zero. This justifies that the model does not suffer from the problem of multicollinearity.

\section{Model Estimation Selection}

In determining the most suitable method of estimation, BP-LM test was conducted in choosing between Pooled OLS vs Random/Fixed Effect Model. A chi-square of 71.15 with $p$-value of 0.0000 was produced by BP-LM Test for random effect, thus rejecting the hypothesis that says the variance of the random effect is zero; this implies that Pooled OLS model is not appropriate for the model. The study then proceeds to running the Hausman test to choose the more suitable between fixed and random effect model.

The Hausman test produces a chi-square of 4.93 with a p-value of 0.6687 which indicates that the null hypothesis is strongly accepted. This implies that the random effect model produces better and consistent estimate than the fixed effect model, thus only the estimate from random effect model are therefore reported to explain the effect of Non-Performing Loans on liquidity of Deposit Money Banks in Nigeria. 
Table 3: Random-Effect Model Result

\begin{tabular}{ll} 
Variable & Random-effect \\
\hline Constant & $3.8808(0.800)$ \\
NPL & $-0.0881(0.018)^{* *}$ \\
CAR & $0.3659(0.022)^{* *}$ \\
BS & $1.3189(0.037)^{*}$ \\
LG & $0.0338(0.354)$ \\
GDP & $-0.7924(0.201)$ \\
MPR & $0.0092(0.983)$ \\
INF & $0.6465)(0.031)^{* *}$ \\
Model estimation & \\
R $^{2}$ within & 0.1166 \\
Wald Chi $^{2}$ & $19.75(0.0061)^{*}$ \\
\hline
\end{tabular}

Note $* *$ and $*$ denote statistically significant at $5 \%$ and $10 \%$ respectively. Also, $p$-values are reported in parentheses

Table 3 shows the linear relationship between Banks' liquidity and the independent variables [Nonperforming Loans (NPL), Capital Adequacy Ratio (CAR), Bank size (BS), Loan Growth (LG), GDP, Inflation and Monetary Policy Rate (MPR)] with the use of panel regression analysis. The table shows the result of Random-effects regression analysis. In terms of direction of the relationship, it can be seen that variables such as Capital Adequacy Ratio, bank size, Loan growth, Monetary Policy Rate and Inflation, maintain a positive relationship with bank liquidity while Non-Performing Loans (NPL) and Gross Domestic Product (GDP) have a negative relationship with liquidity of deposit money banks in Nigeria. In addition, the magnitude of the coefficient shows that four variables: Non-performing loan, Capital Adequacy Ratio, bank size and inflation have significant effect on bank liquidity as indicated by coefficient $(-0.0881,0.3659,1.3189$ and 0.6465$)$ with probability values $(0.018$, $0.022,0.037$ and 0.031 ) at $5 \%$, significance level. Therefore, these four variables are interpreted as follow:

Firstly, result from the findings disclosed that $1 \%$ increase/decrease in Nonperforming loans will induce $9 \%$ decrease/increase in the banks' liquidity. The result of this study is in line with the findings of (Bloem \& Gorter, 2001; Belete, 2015; Ezeamama et al.,2016; Faroq \& Nasir, 2017; Iqbal, 2012; Ionica, 2012; Jane, 2014; Nigist \& Laximikanthan, 2015; Toby, 2008; Tafirei, 2014) while Berhanu(2015); Chikoko(2013); Edirin(2014); Vodova(2011) obtained contradictory outcome as they identified a positive link between banks' liquidity and NPLs. Moreso, the study matches the theory adopted for the study- information asymmetry and moral hazard hypothesis, as banks suffer increased trouble loans consequent to the receipt of inadequate information about their potential borrowers as well as laxity in the implementation of loan policies.

Secondly, result obtained revealed that $1 \%$ increase (decrease) in Capital Adequacy Ratio will cause bank liquidity in Nigeria to increase (decrease) by $\$ 0.37$ hence a positive link between CAR and banks' liquidity is obtained. This finding is consistent with Aymen (2015); Bunda and Desqui(2005); Choon et al., (2013), Faroq and Nasir(2017); Jane (2014); Tseganesh(2012) and Vodova(2011). In a nutshell, increase in bank capital would expand their liquidity creation and also help to regain more public confidence in the service delivery of the industry.

Thirdly, if there is 1 increase/decrease in bank size, it will induce $1 \%$ increase (decrease) in bank liquidity in Nigeria. Result obtained showed a positive relationship 
between bank size and banks' liquidity. This result is premised on the fact that large deposit holdings coupled with access to external sources of funds, help to enhance banks' liquidity. This result tends to contrast the findings of Choon et al.(2013); Faroq and Nasir (2017); Rauch, Steffen, Hackethal and Tyrell (2009); Tannotta, Nocera and Sironi (2007) which incited a negative correlation between the two concepts concerned.

Lastly, $1 \%$ increase/decrease in inflation rate will induce bank liquidity in Nigeria by N0.65. This result is in support of Moussa(2015), Bhati and De zoysa (2012), Anamika and Anil (2016) and Belete (2015) who identified positive relationship between inflation and bank liquidity. However, this finding tends to contrast the empirical findings of Tseganesh (2012), Vodova (2011) as negative results were realised.

On the other hand, Loan Growth, Gross Domestic Product and Monetary Policy Rate have been identified as maintaining insignificant influence on the banks' liquidity as it is apparent in their coefficients $(0.0338,-0.7924$ and 0.0092$)$ with their respective P-values (0.354, 0.201 and 0.983). Result obtained is consistent with Vodova (2011) and Belete (2015) and in contrary to the findings of Vodova (2013); Moussa (2015); Bunda and Desquilbel (2008); Choon et al., (2013); Anamika and Anil (2016); Faroq and Nasir (2017).

\section{Conclusion and Recommendations}

This study examines the effect of Non-performing loans on liquidity of deposit money banks in Nigeria. The author made use of panel data regression analysis to determine the relationship between banks liquidity (dependent variable) and NPL while taking into consideration the effect of other variables such as: CAR, LG, BS, MPR, INF and GDP. The empirical findings from this study revealed that NPLs maintain significant but negative effect on the banks' liquidity while CAR, BS and INF were significant and positively related with banks' liquidity. GDP, MPR and LG were identified insignificant in relation to banks' liquidity. The author infers consequently that Nigerian banks might continue to suffer liquidity constraints if the tides of NPLs in the industry are not adequately addressed. Moreso, banks with adequate CARs are observed more capable to withstand economic tension than others with low CARs. In addition, these banks were also observed to increase better and faster in size in terms of branch network, liquidity etc. than others. It becomes important therefore that the banks set their liquidity priority aright as huge unpaid loans resulting from lending, stand to threaten their continuity. In line with this finding, the following recommendations are made:

The Central bank should ensure, with strict compliance that adequate loan loss provisions are required of banks so that unexpected high credit risk is eliminated minimally. In addition, the Central bank should ensure strict compliance of banks with the incumbent NPLs tolerable limit of $5 \%$ by requiring all loan applications for adequate scrutiny before approval.

The Central bank should promote the growth of banks' resilience and public confidence in the industry by ensuring the banks' steady compliance with the regulatory limit of CAR which in turn influences their stability and continuity of operation.

The central bank should allow small banks extensive access to its window facility in order to salvage emergency situations especially when bad loans erode more of their capital. Moreso, these banks should be encouraged to invest in productive portfolio whose return could be used to enhance their growth and size.

\section{Limitation of the Study and Future Direction}


The limitation of this study is attributed to sources of data used, as it was very difficult to source for the data from the CBN and National Bureau of Statistics. The choice of variables for this research work was another limitation in this study, though, through the efforts of my colleagues, we are able to come over the challenge as the right variables was used for the study. The time scope was a big challenge to the study, in order to create a research gap for this study a reliable period was used for the study.

The future direction of this study should be focused on other financial institutions other than the deposit money banks as this will allow us to determine the non-performance loans and liquidity in non-interest banking and other financial institutions in the country. Other areas such as the insurance companies should also be focused in the future in this areas of study as it will allow us to know the experience of non-performing loans and liquidity in the insurance companies. In future, African countries should be looked into critical with respect to non-performing loans and liquidity of the deposit money banks.

\section{References}

Akhigbe, O. J., \& Akhigbe, E. A. (2021). Organisational Transparency and Effectiveness of Deposit Money Banks in Rivers State, Nigeria. Journal of International Business and Management, 4(4), pp. 01-14.

Anamika, S. \& Anil, K. S. (2016). An empirical analysis of macroeconomic and bank specific factors affecting liquidity of Indian banks. Future Business Journal, 2, 4053

Bhati, S.S. \& De Zoysa, A. (2012). An examination of factors affecting liquidity management in Indian financial system; Sixth Annual International Conference on Business and Society in a Global Economy (pp.21)

Bunda, I. \& Desquibet, J. B. (2008). The bank Liquidity Smile across exchange rate regimes. International Economic Journal,22(3), 361-386

Bloem, A.M. \& Gorter G. N.(2001). Treatment of Non-performing Loans in Macroeconomic Statistics, International Monetary Fund, Working Paper 20012009

Berhanu, B. E. (2015). Determinants of bank Liquidity and their impact on profitability: Evidence from eight commercial banks in Ethiopia

Bonny, A. \& Motolani, O. (2017). High Non-performing loans put banks at risk of collapse. Retrieved from www.dailytimes.ng/business/high-non-performiongloans-put-banks-at-risk-of-collapse

Bamoriya, P. \& Jain, R. (2013). Non-Performing Assets (NPA) and Select Key Financial Heads: an Empirical study of commercial banks of India using Multiple Regression Modelling. The Journal of Accounting and Management, 2, 19-25

Chikoko, L. (2013). Zimbabwean Commercial Banks' Liquidity Risk Determinants after Dollarisation. Journal of Applied Finance and Banking, 3(6), 97-114

CBN (2016). Central Bank of Nigeria Financial Stability Report. Retrieved from www.cbn.gov.ng

Clementina, K. \& Hamilton, O. I. (2014). The rising incidence of Non-Performing Loans and the nexus of economic performance in Nigeria: an investigation. European Centre for Research Training and development, 2(5), 87-96

Choon, L. K., Hooi, L. Y., Murthi, L., Yi \& Shven, T. Y.(2013). The determinants influencing liquidity of Malaysia Commercial banks and its implication for 
relevant bodies: Evidence from 15 Malaysian commercial banks. Retrieved from http://eprints.utar.edu.my

Daniel, E. B. (2016). Liquidity Management and Performance of Deposit Money Banks in Nigeria. International Journal of Economics, Finance and Management Sciences, 5(3), 146-161

Diamond, D. W. \& Dybvig, P. H. (1983). Bank runs, Deposit Insurance and Liquidity. Journal of Political Economy, 91(3), 401-419

Dinger V. (2009). Do Foreign-owned banks affect banking system liquidity risk? Journal of Comparative Economics. 37(4), 647-657

Edirin (2014). Assessing the relationship between NPLs and the financial soundness of banks in Nigeria (2003-2012). Journal of Arts and Social Sciences, 3(1), 115-125

Ezeamama, M. C., Onwuliri, O. C. \& Okoye, J. O. (2016). Liquidity Management in banks: a study of selected commercial banks in Nigeria (2000-2009)

Faroq, A. \& Nasir, R. (2017). Determinants of bank Liquidity: Empirical evidence from listed commercial banks with State Bank of Pakistan. Journal of Economics and Sustainable Development, $8(1)$

Gakpo, M. D. Y. Anafure. A. I. \& Mensah, J. K. (2021). Understanding the Importance and Practices of Operational Risk Management in Ghanaian Banks. Journal of International Business and Management. Journal of International Business and Management 3(4): pp. 01-09.

Godwin, E. B., \& Comfort, E. M. (2015). Bank Profitability and Liquidity Management: A case study of selected Nigerian DMBs. International Journal of Economics, Commerce and Management, 3(1).

Iqbal, A. (2012). Liquidity Risk management: A comparative study between Conventional and Islamic banks of Pakistan. Global Journal of Management and Business Research, 12(5), 55-64

Ioan T., Nicolae P. \& Emilia A. C.(2015). Impact of Macroeconomic variables upon the banking system liquidity. Procedia Economics and Finance Journal, 32, 11701177

Ionnotta, G., Nocera, G. \& Sironi, A. (2007). Ownership structure, Risk and Performance in the European Banking Industry. Journal of Banking and Finance, 31(7), 21272149

Jaffee, D.M. \& Russell, T. (1976).Imperfect Information, Uncertainty and Credit rationing. Quarterly Journals of Economics, 90(4), 651-666

Jane, W. M. (2014). The effect of Non-Performing Loans on liquidity risk of commercial banks in Kenya

Joseph, M. T., Edson, G., Manuere, F., Clifford, M. \& Michael, K. (2012). Nonperforming Loans in Commercial banks; A case of CBZ Bank Limited in Zimbabwe, Interdisciplinary Journal of Contemporary Research in Business, 4(7), 476-488

Johannes, P. S., Sheefeni \& Jacob M.N. (2016). Macroeconomic Determinants of Commercial Banks Liquidity in Namibia. European Journal of Business, Economic and Accountancy, 4(5)

Lawrence, B. \& Foluso I. (2017). Effect of Credit Risk Management on performance of Deposit Money Banks in Nigeria. Retrieved from www. punchng.com/effect-ofcredit-risk-management-on performance-of deposit-money-banks-in-nigeria 
Munteanu, I.(2012). Bank Liquidity and its determinants in Romania. Procedia Economics and Finance Journal, 3, 993-998

Moore, W. (2009). How do financial crises affect commercial banks' liquidity? Evidence from Latin America and the Caribbean, Paper 21473, University Library of Munich.

Muhammed, U. \& Gang, S.(2016). Non-performing Loans (NPLs), Liquidity Creation and Moral Hazard: case of Chinese banks. Umar and Sun Chinese Finance and Economic Review, 4(10)

Moussa, M.A. B. (2015). The determinants of bank Liquidity: case of Tunisia. International Journal of Economics and Financial Issue, 5(1), 249-259

Nzioka, C., \& Kariuki, P. (2021). Influence of Strategic Internal Factors on Competitive Advantage of Commercial Banks in Nairobi County, Kenya. Journal of International Business and Management, 4(7), 01-16.

Owino, M. O., Wagude, J., \& Mulwa, J. M. (2021). The Assessment of the Effect of Firm Size on Competitiveness of Commercial Banks in Kenya. Journal of International Business and Management 4(8), pp. 01-14.

Ratnovski, L. (2013).Liquidity and Transparency in Bank Risk Management. Journal of Finance Intermediation, 22(3), 422-439

Rauch, C., Steffen, S., Hackethal, A. \& Tyrell, M. (2009). Savings banks, Liquidity creation and Monetary Policy, retrieved from: http://wwwwiwi.unifrankfurt/Determinants-of-bank-liquidity-creation.pdf

Samuel, O. (2017). Banks' non-performing loans hit $\$ 2$ tn-CBN. Retrieved from www.punchng.com/banks'-non-performing-loans-hit- $\$ 2$ tn

Samuel, O.F. (2011). Banking sector Liquidity and Financial crises in Nigeria. International Journal of Economics and Finance, 3(5), n.p.

Somoye, R. O. C. (2016). The variation of risk of non-performing loans on bank performance in Nigeria. Indian Journal of Economics and Business, 9(1), 87-99

Toby, A. J. (2008). Monetary Policy, Capital adequacy and banking system soundness in Nigeria, Journal of Financial management and Analysis, 21(1), 32-46

Umar, M. \& Sun, G. (2016). Non-performing Loans, Liquidity Creation and Moral hazard: case of Chinese banks, Chinese Finance and Economic Review, 4(1), 1-23

Uremadu, S. O. (2009). Determinants of Financial System Liquidity (1980-2005): Evidence from Nigeria. Annals of University of Bucharest, Economic and Administrative Series, 3, 123-137

Vodova, P. (2013). Determinants of Commercial bank Liquidity in Hungary, e-finanse Financial Internet Quarterly, 9(3), 64-72

Vodova, P. (2011). Liquidity of Czech Commercial banks and its determinants. International Journal of Mathematical Models and Methods in Applied Sciences, 5(6), 1060-1067.

World Bank Group (2016). Annual Average NPLs of banks in Nigeria. Retrieved from http://data.worldbank.org 